\title{
カーボンブラック反応炉の流動解析
}

西脇勝也○ (旭カーボン(侏) 鈴木修（旭カーボン侏）高見潤一（旭カーボン(侏） 松原幸治（新潟大）小林睦夫（新潟大）

\section{Carbon black reactor analysis}

\author{
Katsuya NISHIWAKI, Osamu SUZUKI, Junichi TAKAMI, Koji MATSUBARA, and Mutsuo KOBAYASHI
}

\begin{abstract}
Isothermal gas simulation was performed for three patterns of carbon black (CB) reactors using standard $\mathrm{k}-\varepsilon$ model to treat turbulent flow. In addition, Lagrangean simulation was made to predict flow time corresponding to the time span of CB traveling in the hot gasses. Numerical results thus obtained are compared with geometrical properties of $\mathrm{CB}$ aggregate sampled from the $\mathrm{CB}$ reactors whose geometric shapes are the same as the numerical models. Numerical data suggested that flow time is key to control indicators of $\mathrm{CB}$ aggregate size.
\end{abstract}

Key Words: Carbon black reactor model, Numerical Simulation, CB geometrical property, Flow time

1.はじめに カーボンブラック (CB) は, 工業的に製造 されるすすであり，ゴム製品およびタイヤの補強剤や黒色 顔料等として利用されている(1).工業材料として CB を用 いる場合， CB 凝集体寸法やその分布が重要になるが、そ れらの制御は経験によってなされているのが現状である. 本研究では，CB 反応炉モデルに対して数值解析を行い， 計算結果を実際にサンプルした C B 凝集体の幾何特性と比 較し，CBの凝集機構について考察する。

2. 計算手法 ファーネス方式 C B反応炉では，高温燃焼 ガス流中において原料油を熱分解することでC B を生成し 水噴䨏によって反応を停止させる．解析対象とするC B反 忘炉モデルを図 1 に示す。本計算では, $\mathrm{CB}$ 生成領域（図 の斜線部）に対して気流解析を行い，また原料油噴霛位置 から反応停止位置までの流体粒子の滞留時間を求める。

気流解析では，実際にC B 粒子をサンプルした 3 種類の 炉形状 R1，R2 および R3（図 2 参照）を取り上げ，原料 油と水を考虑せず非圧䌦性・等温気流に対して2 次元定常 解析を行った．乱流モデルとして標準形 $\mathrm{k}-\varepsilon$ モデルを用 い，また壁面ではスリップ条件を適用した。流速条件の表 示には流入速度 $\mathrm{U}_{0}$ と絞り部直径 $\mathrm{D}$ を基準とするレイノル ズ数 Re を用いるものとし， $R e=67,000,89,000,150,000$ において計算を行った. 同じ手法による二次元後ろ向きス テップ流に対する計算によると，スリップ条件を用いたた め壁面近傍の乱れは再現できなかったが，ステップ背後に おける循環流域の寸法とステップ下流部における乱れ強さ は既存の実験值(2)とほぼ一致することが示された。

滞留時間解析では，気流解析領域の入口断面から出口断 面までの滞留時間を粒子追跡法によって計算し，その外側 において一様流を仮定して得られる滞留時間を加えること で，CB生成炉モデル全体に対する滞留時間とした。一部 の検討では乱流拡散を無視したが，これを考慮する場合は ランダムウォークによって模擬した，壁面境界条件として 完全弹性衝突を仮定した。このようにして得られる滞留時
間は，原料油の蒸発速度と CB 生成速度をともに無限大と 仮定した場合の CB 凝集体のそれに対応する。

3. 沮度の推定 表 1 に実験条件を示す。予備実験によ ると, 絞り部 (気流解析領域入口部) 上流側の燃焼領域に おける放熱損失は燃料低発热量の約 20 パーセントであっ た。この結果を参考にして推定した絞り部温度 $\mathrm{T}_{0}$ を表 2 に記入した。 また， $\mathrm{CB}$ 生成領域において原料油の熱分解 反応，それにより生じる CB と水素の酸化反応を考慮し，

これらの反応が完了したと仮定して得られる炬内最終温度 $\mathrm{T}$ も表 2 に記した。文献(3)の検討から，このような温度推 算法の妥当性が示唆されている，参考のため，燃焼領域に おいて完全燃焼を仮定して計算された絞り部残存酸素濃度 も表 2 に示した. Toが約 300Kのバラツキを示すが，然焼 領域における空気過剩率が異なるためである。 き $\mathrm{T}_{1} か ゙$ 高くなるのは，この場合に絞り部における残存酸素 量が大きく，発熱反応である酸化反応が多く生じるためで ある。

\section{4. 計算結果}

4. 1 炉内流称特性 $\mathrm{Re}=89,000$ に対する乱流エネルギ 一の分布を図 2 に示す。炬形状 $\mathrm{R} 3$ では， $\mathrm{x} / \mathrm{D}=7.1 \sim 10$ に 設けた第 2 絞り部によって流れが強く加速されるため，そ の下流部で乱れが大きくなる。これに対して，炬形状 R2 では徐々に流路直径が大きくなるため流れは比較的緩やか に変化し，乱れが最も弱く，炉形状 R1 では乱れが中間的 な強さを示す。なお，本計算では壁面による低レイノルズ 数効果孛無視したため, Re=67,000,89,000，150,000に おいてレイノルズ数依存性は極めて小さいことが示された (図省略).

4. 2 清留時间 乱流桩散の影響を考慮した解析に加え て循環流域の影響を知るため乱流拡散を意図的に無視した 解析を行い，両方の結果を比較した。それによると，乱れ の影響によって流体粒子の一部が循環流域内を通過するよ うになるため, 乱流拉散を考慮すると滞留時間の平均值 が 3 パセセント程度大きくなり，その標準偏差 $\mathrm{t}_{\mathrm{f}, \mathrm{rms}}$ が 3 
～6 倍に大きくなった (図省略)，後述のように滞留時間は $\mathrm{CB}$ の幾何学特性を決める重要な要因であるため, 循環流 域の存在が C B 特性に影響している可能性が示唆された.

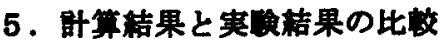

前述のように本計算ではレイノルズ数効果が十分小さ

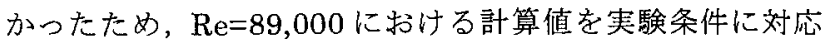
する $\mathrm{U}_{0}$ と D でスケーリングして用いる。 CB は複雑な凝 集構造(1)を有するが，その幾何特性を表す量として， CB 吸油量に相当する $24 \mathrm{M} 4 \mathrm{DBP}$ 値に注目する.

図 3では, 24M4DBP と平均滞留時間 可 の無次元化には，流入速度の影響を顕示するため速度ス ケールv/D と長さスケール D を用いた。図 3 から，全体 的に $24 \mathrm{M} 4 \mathrm{DBP}$ と滞留時間に正の相関が有り，滞留時間が 長くなると CB 凝集体がより発達することが示崚されてい る.図 4 では, 24M4DBP と乱流エネルギ一の相関を示す. 図 4 から，乱流エネルギーと $24 \mathrm{M} 4 \mathrm{DBP}$ には正の相関が ある．炉形状 R3 では，第 2 絞り部の下流で乱流エネルギ 一が大きくなるため，他の炉形状とは特異的である．以上 のことから，CB 凝集体サイズは滞留時間および乱流エネ ルギーと正の相関があることが示唆されるが，凝集体サイ ズには原料油接触効率，炉断面内の原料油蒸気濃度も影響 すると考えられ，詳細については不明である。

\section{6. 結言}

C B 反応炉に対して気流解析と滞留時間を行い，それら の結果を C B 凝集体に関する実験值と比較検討し，CB 吸 油量 (24M4DBP) に対する滞留時間の影響を明らかにし た.

\section{沶女地}

（1）久英介ら，カーボンブラック便覧，カーボンブラック協会編， 1995.

（2）笠木ら，第 9 回流体計測，第 6 回流体制御合同シンポジウム 講演論文集, (1991)，77-82.

(3) 青木・三浦, ケミカルエンジニアリング, 1998(1), 11-17.

Table 1 experimental conditions.

\begin{tabular}{|l|c|c|c|c|c|c|}
\hline Case & Geom & $\mathrm{Re}$ & $\mathrm{L}_{\mathrm{t}}$ & $\mathrm{L}_{\mathfrak{e}}$ & $\begin{array}{c}\mathrm{AR} \\
{[\mathrm{kg} / \mathrm{kg}]}\end{array}$ & $\begin{array}{c}\mathrm{MOR} \\
{[\mathrm{kg} / \mathrm{kg}]}\end{array}$ \\
\hline $\mathrm{R} 1-1$ & $\mathrm{R} 1$ & 67000 & $1.1 \mathrm{D}$ & $46.4 \mathrm{D}$ & 1.15 & 0.104 \\
\hline $\mathrm{R} 1-2$ & $\mathrm{R} 1$ & 84000 & $4.5 \mathrm{D}$ & $46.4 \mathrm{D}$ & 1.27 & 0.092 \\
\hline $\mathrm{R} 1-3$ & $\mathrm{R} 1$ & 85000 & $6.0 \mathrm{D}$ & $46.4 \mathrm{D}$ & 1.29 & 0.084 \\
\hline R2-1 & $\mathrm{R} 2$ & 68000 & $1.1 \mathrm{D}$ & $53.6 \mathrm{D}$ & 1.16 & 0.12 \\
\hline R2-2 & $\mathrm{R} 2$ & 150000 & $4.5 \mathrm{D}$ & $53.6 \mathrm{D}$ & 1.58 & 0.068 \\
\hline R2-3 & $\mathrm{R} 2$ & 150000 & $6.0 \mathrm{D}$ & $53.6 \mathrm{D}$ & 1.58 & 0.063 \\
\hline R3-1 & $\mathrm{R} 3$ & 81000 & $1.1 \mathrm{D}$ & $56.4 \mathrm{D}$ & 1.13 & 0.097 \\
\hline $\mathrm{R} 3-2$ & $\mathrm{R} 3$ & 94000 & $4.5 \mathrm{D}$ & $56.4 \mathrm{D}$ & 1.27 & 0.074 \\
\hline
\end{tabular}

Geom= reactor geometry, $\mathrm{Re}=$ Reynolds number,

$\mathrm{L}_{\mathrm{t}}=$ length between oil spray and first expansion,

$L_{e}=$ length between first expansion an $d$ water spray,

$A R=$ air ratio in combustion region,

$\mathrm{MOR}=$ flow rate ratio of material oil to combustion gasses

Table 2 Estimated values of temperature.

\begin{tabular}{|c|c|c|c|c|}
\hline Case & $\begin{array}{c}\mathrm{AR} \\
{[\mathrm{kg} / \mathrm{kg}]}\end{array}$ & $\begin{array}{c}\mathrm{OR} \\
{[\mathrm{kg} / \mathrm{kg}]}\end{array}$ & $\begin{array}{c}\mathrm{T}_{0} \\
{[\mathrm{~K}]}\end{array}$ & $\begin{array}{c}\mathrm{T}_{l} \\
{[\mathrm{~K}]}\end{array}$ \\
\hline $\mathrm{R} 1-1$ & 1.15 & 0.0301 & 2060 & 1808 \\
\hline $\mathrm{R} 1-2$ & 1.27 & 0.0482 & 1950 & 1882 \\
\hline $\mathrm{R} 1-3$ & 1.29 & 0.0507 & 1934 & 1914 \\
\hline $\mathrm{R} 2-1$ & 1.16 & 0.0312 & 2053 & 1754 \\
\hline $\mathrm{R} 2-2$ & 1.58 & 0.0828 & 1733 & 2033 \\
\hline $\mathrm{R} 2-3$ & 1.58 & 0.0828 & 1733 & 2056 \\
\hline $\mathrm{R} 3-1$ & 1.13 & 0.0258 & 2178 & 1909 \\
\hline $\mathrm{R} 3-2$ & 1.27 & 0.0468 & 2056 & 2037 \\
\hline
\end{tabular}

$\mathrm{OR}=$ oxigen ratio at throat, $\mathrm{T}_{0}=$ throat temperature,

$\mathrm{T}_{I}=$ temperature at fully developed stage,

see Table 1 for AR.

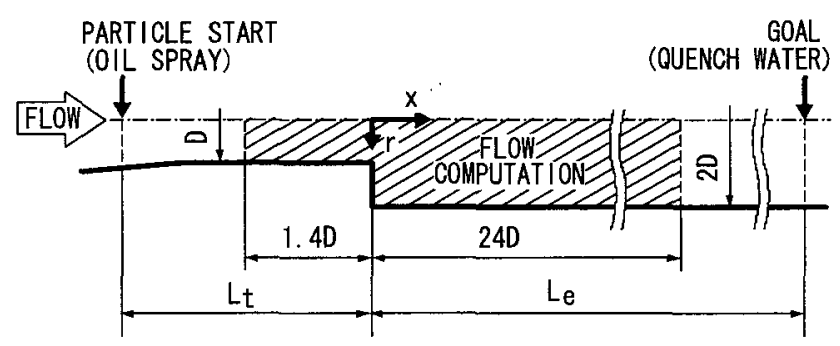

Fig. 1 Carbon black reactor model.

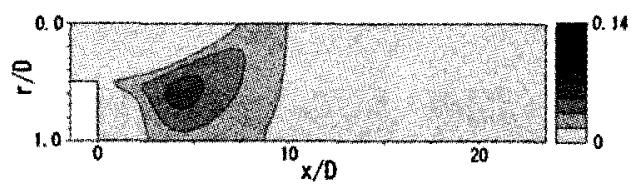

(a) R1

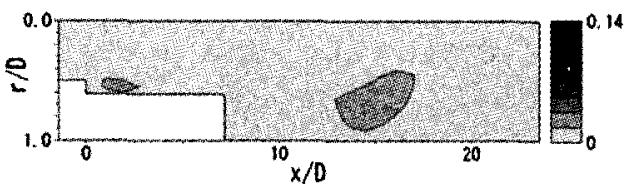

(b) R2

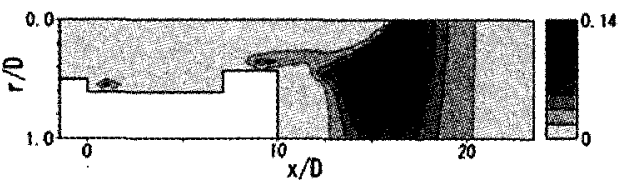

(c) $R 3$

Fig. 2 Turbulence energy, $\mathrm{k} / \mathrm{U}_{0}{ }^{2}$.

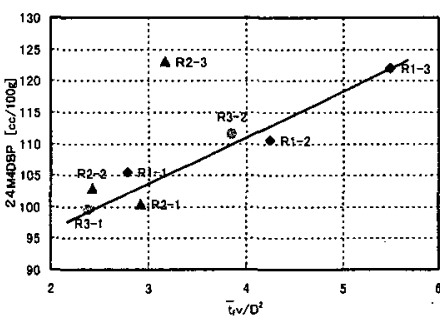

Fig.3

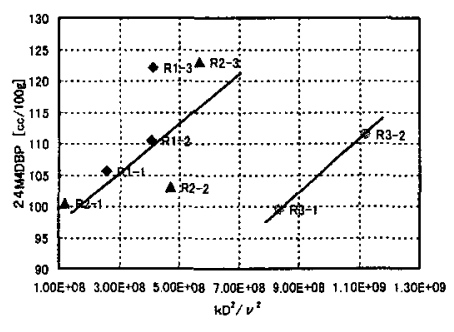

Fig4 